\title{
Where is the right ventricle?
}

\author{
Muhammed Oylumlu, ${ }^{1}$ Adnan Dogan, ${ }^{1}$ Suleyman Ercan, ${ }^{2}$ Vedat Davutoglu ${ }^{2}$
}

'Department of Cardiology, Dumlupinar University, School of Medicine, Kutahya, Turkey ${ }^{2}$ Department of Cardiology, Gaziantep University, Gaziantep, Turkey

\section{Correspondence to} Dr Suleyman Ercan, sleymanercan@yahoo.com

Accepted 15 March 2014
CrossMark

To cite: Oylumlu $\mathrm{M}_{\text {, }}$ Dogan A, Ercan S, et al. BMJ Case Rep Published online: [please include Day Month Year] doi:10.1136/ bcr-2013-202760

\section{DESCRIPTION}

A 20-year-old man with no history of known cardiac disease was admitted with dyspnoea on exertion during a few weeks. His effort capacity was class I. At physical examination, his blood pressure was 120 / $70 \mathrm{~mm} \mathrm{Hg}$ and pulse $80 \mathrm{bpm}$. His physical examination and ECG were unremarkable. Room air oxygen saturation was measured as 91 when evaluating patients on admission. Transthoracic echocardiography revealed that the left ventricle, left atrium and right atrium were of normal structure and function; however, the right ventricle (RV) was severely hypoplastic with an intact interatrial septum (figure 1 and video 1). Also, in the echocardiographic evaluation of patients, tricuspid regurgitation was present in trace amounts. Transoesophageal echocardiography further disclosed that the tricuspid valve and right ventricular outflow tract were normal (figure 2 and video 2). The echocardiographic parameters and values of the patients in our study were recorded as follows: tricuspid valve annulus: $2.3 \mathrm{~cm}$, tricuspid valve annulus $Z$ score: -6.95 , mitral valve annulus: $3.3 \mathrm{~cm}$, mitral valve annulus $Z$ score: -0.73 , RV area: $8 \mathrm{~cm}^{2}$, RV area $\mathrm{Z}$ score: -7.54 . Cardiac catheterisation for further investigation was recommended to the patient diagnosed with isolated right ventricular hypoplasia. However, the patient refused further investigations.

Isolated hypoplasia of RV, unassociated with severe pulmonary or tricuspid valvular malformation, is a rare kind of congenital heart disease. Two main features of isolated hypoplasia of RV are the absence of the trabecular portion of RV and the presence of normally developed tricuspid and pulmonary valves. The degree of hypoplasia has a

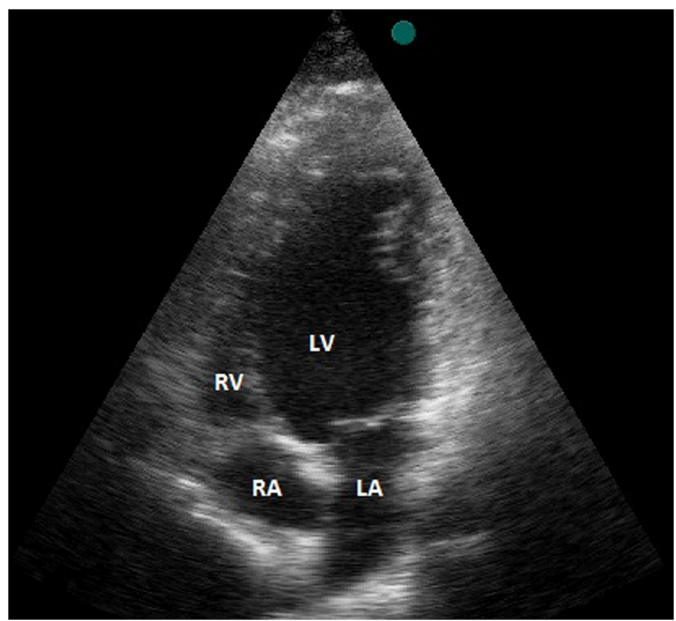

Figure 1 Transthoracic echocardiography revealed that the left ventricle (LV), left atrium (LA) and right atrium (RA) were of normal structure; however, the right ventricle (RV) was severely hypoplastic with an intact interatrial septum.

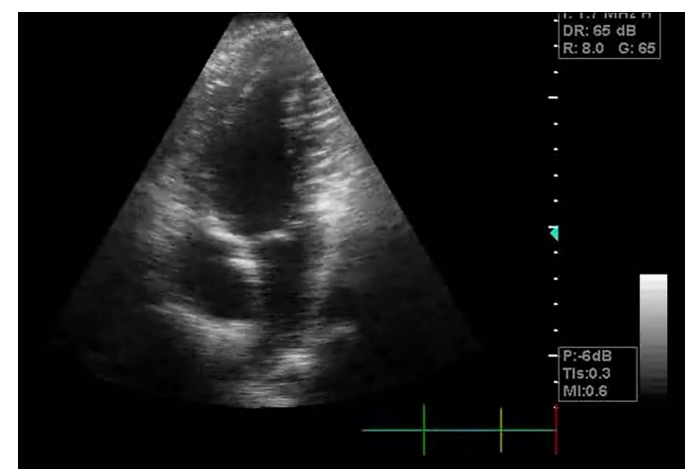

Video 1 Transthoracic echocardiography revealed that the left ventricle, left atrium and the right atrium were in normal structure and function; however, right ventricle was severely hypoplastic with intact interatrial septum.

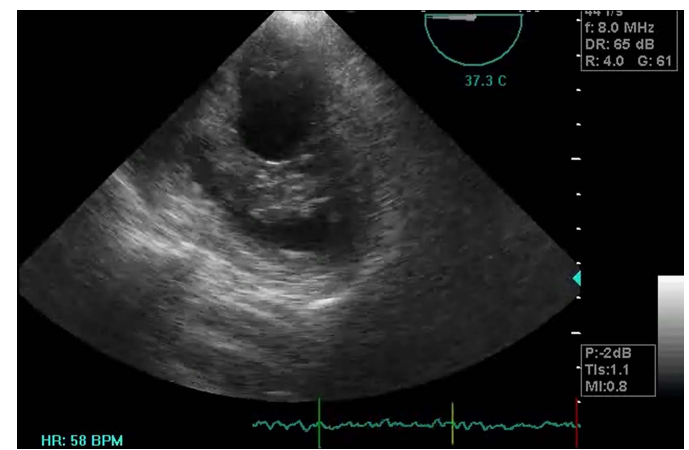

Video 2 Transesophageal echocardiography further disclosed that tricuspid valve and right ventricular outflow tract were normal.

significant effect on the variations in the clinical

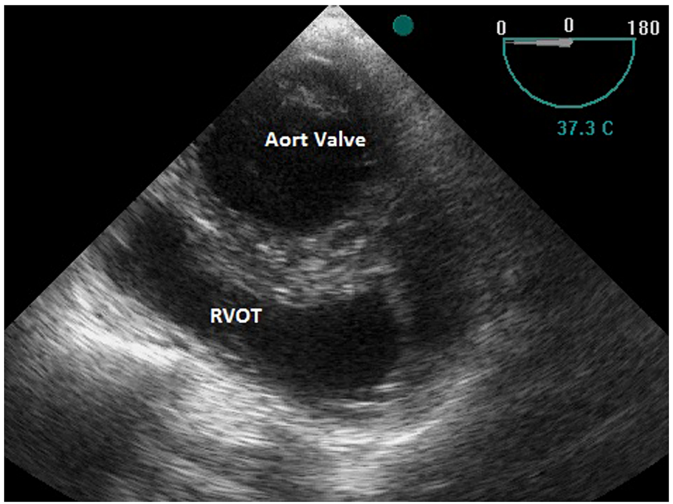

Figure 2 Transoesophageal echocardiography showed that the tricuspid valve and right ventricular outflow tract (LVOT) were normal. 
spectrum. Severe forms of hypoplasia were reported to be seen mostly in infancy and to resemble tricuspid or pulmonary atresia, usually with cyanosis in childhood in the reported cases. ${ }^{12}$ It

\section{Learning points}

Isolated hypoplasia of the right ventricle is rarely seen without severe symptoms.

- When the right ventricle cannot be visualised in the routine echocardiographic examination, the diagnosis of the isolated hypoplasia of the right ventricle should be discussed.

- Two main features of isolated hypoplasia of RV are the absence of the trabecular portion of RV and the presence of normally developed tricuspid and pulmonary valves. must be noted that lesser degrees of hypoplasia resemble Ebstein's malformation and anomalies of the systemic venous return. As in our case, isolated hypoplasia of RV is rarely seen without severe symptoms.

Contributors $\mathrm{MO}$ was involved in the clinical following and approval of the case. $A D$ and $V D$ were involved in the design, interpretation and editing of the language of the manuscript. SE was involved in the echocardiographic examination.

Competing interests None.

Patient consent Obtained.

Provenance and peer review Not commissioned; externally peer reviewed.

\section{REFERENCES}

1 Chessa M, Redaelli S, Masszi G, et al. Familial occurrence of isolated right ventricular hypoplasia. Am J Med Genet 2000;90:356-7.

$2 \mathrm{Kim} \mathrm{H}$, Park EA, Lee W, et al. Magnetic resonance imaging findings of isolated right ventricular hypoplasia. Int J Cardiovasc Imaging 2012;2:149-52.

Copyright 2014 BMJ Publishing Group. All rights reserved. For permission to reuse any of this content visit http://group.bmj.com/group/rights-licensing/permissions.

BMJ Case Report Fellows may re-use this article for personal use and teaching without any further permission.

Become a Fellow of BMJ Case Reports today and you can:

- Submit as many cases as you like

- Enjoy fast sympathetic peer review and rapid publication of accepted articles

- Access all the published articles

- Re-use any of the published material for personal use and teaching without further permission

For information on Institutional Fellowships contact consortiasales@bmjgroup.com

Visit casereports.bmj.com for more articles like this and to become a Fellow 